College of William \& Mary Law School William \& Mary Law School Scholarship Repository

1940

\title{
The Development of State Statutes on Negotiable Paper Prior to the Negotiable Instruments Law
}

Frederick K. Beutel

\section{Repository Citation}

Beutel, Frederick K., "The Development of State Statutes on Negotiable Paper Prior to the Negotiable Instruments Law" (1940).

Faculty Publications. 1049.

https://scholarship.law.wm.edu/facpubs/1049

Copyright c 1940 by the authors. This article is brought to you by the William \& Mary Law School Scholarship Repository. https://scholarship.law.wm.edu/facpubs 


\section{THE DEVELOPMENT OF STATE STATUTES ON NEGOTIABLE PAPER PRIOR TO THE NEGOTIABLE INSTRUMENTS LAW*}

Much has been said and written about the conflict of the cases on Negotiable Instruments prior to the adoption of the Negotiable Instruments Law. Based on the assumption that courts of the various jurisdictions had departed from the true line of the authoritative English common law, it has been assumed that the Negotiable Instruments Law was a codification of the common law of this country which attempted to bring the courts back into line. Very little has appeared about the development of the statutory background of the Negotiable Instruments Law. The purpose of this paper is to examine the growth of legislation in the field in an effort to throw some light upon the condition of the law at the time of the adoption of the Act.

Colonial Development of the Law at the Tiare of the ReVolution

As indicated elsewhere, ${ }^{1}$ the laws of the colonies on the subject of commercial paper were by no means uniform at the time of their separation from England. There were, however, a number of outstanding features which were appearing fairly consistently throughout the colonies and which sharply distinguished the colonial law from that of the mother country.

In the first place, the law of the colonies on this subject was almost sui generis, based on early colonial statutes emanating chiefly from New England. The law of assignment in general and commercial paper in particular was well-established throughout the colonies. Unlike the English law, statutes giving the assignee the right to sue in his own name almost uniformly preceded the right of a holder to cut off defenses.

Aided also by colonial statutes, the negotiability of notes, bills of exchange and bonds was well known throughout the colonies and had developed at least a century ahead of the English law. In New England these advances were achieved not only by statutes, but by decisions

*. The writer is greatly indebted to Philander S. Ratzkoff of the Boston Bar who aided in collecting most of the state statutes cited, and to John Vance, Law Librarian of Congress, for generous aid in investigating early statutes and texts.

${ }^{1}$ Beutel, Colonial Sources of the Negotiable Instruments Law of the United States, (1939) 34 IrL. L. Rev. 137. The short resume of colonial law which follows is a summary of that article. 
of courts which were the direct successors to the staple courts of England. In other colonies the Dutch influence together with local statutes aided the development of negotiability long before the Statute of Anne appeared in the mother country. Instruments payable in goods, as well as money, had achieved negotiability before the Revolution, not only in New England, but in many other colonies. 'Though varying widely in its details, as a whole it could be said that the concept of negotiability was modern in its development, and such effect as the common law of England had, was to retard rather than to aid the development of colonial commercial law concepts.

\section{Major Factors Affecting the Post-Revolutionary Laws on Commercial Paper}

After the Revolution, the confusion in the laws of the new United States as they affected commercial paper was accelerated by five major influences which consistently contested for mastery of the prevailing systems in each of the original thirteen states and the vast territories which were thereafter admitted to statehood. These diverting influences were: (1) the English common law, (2) the traditional law merchant, (3) strong commercial, political and sentimental hostility to the English law, (4) the growth of new banking systems to regulate the precarious monetary and credit conditions which accompanied the development of the states, and (5) the enactment of new statutes continuing the influence of the colonial laws and commercial customs.

\section{The Influence of the Common Law}

Though at the close of the Revolution the colonies achieved their political independence from England, it is interesting to note that they actually became more dependent upon the English common law. This change in attitude was accounted for by a number of circumstances.

Finding themselves in a period of chaos without any general system of authoritative laws, a number of states, by constitution or statutes, adopted the common law of England without stopping to consider its effect upon any particular field of the substantive law. Three of the original states, New York, ${ }^{2}$ New Jersey ${ }^{3}$ and Maryland, ${ }^{4}$ adopted the English common law by constitutional provision. Four others of the

${ }^{3}$ N. Y. Const. (1777) Art. XXXV (common law of England, Statutes of England, Acts of Colonial Legislatures as of April 19, 1775).

${ }^{3}$ N. J. CONST. (1776). "Common law of England as well as much of the statute law as had been heretofore practical in this colony shall still remain in force." Minutes of Provincial Congress of New Jersey (1789) 558.

MD. Declaration of Rights and Const. (1776) (the common law as of 
original thirteen states, Georgia, ${ }^{5}$ North Carolina, ${ }^{8}$ Pennsylvania ${ }^{7}$ and Virginia, ${ }^{8}$ adopted the English common law by statute shortly after the Revolution. Rhode Island ${ }^{9}$ and South Carolina ${ }^{10}$ late in the colonial period also had adopted the English common law by statute and probably considered it in force after the Revolution.

As to the other four, Connecticut, Massachusetts, New Hampshire and Delaware, there is considerable doubt. Since contemporary authorities seemed to regard the English common law as being in force only so far as it was affirmatively adopted by each state, it seems clear that the first did not formally take over the English common law. ${ }^{11}$ Massachusetts, which throughout colonial history had been notoriously hostile to the common law, simply adopted, by constitution, "all the laws which have heretofore been adopted, used and approved in the Providence, Colony or State of Massachusetts-Bay and usually practiced on in the courts of law."12 New Hampshire also merely adopted the laws theretofore in force in the colonies. ${ }^{13}$

The Northwest Territory adopted the English common law by statute in $1795^{14}$ and most of the states carved out of it inherited the system. ${ }^{15}$ Vermont, the first new state to be admitted to the union, adopted the common law as of $1760 .^{18}$ Many other states and territories, on being admitted to the control of the United States, also adopted the common law ; ${ }^{\mathbf{1 7}}$ but a large number of the states used the fourth

June 1, 1774); see also 1 Kent's Commentaries (Holmes 12th ed. 1873) $* 473 \mathrm{n}$. 3 Act of Feb. 25, 1784; see 1 Kent's Commentaries (Holmes 12th ed. 1873) *473 n.

${ }^{8}$ N. C. Stat. 1778 , c. 133 ; N. C. Rev. Stat. (1837) c. 22 ; see also 1 Kent's CoMMENTARIES (Holmes 12th ed. 1873) *473 $\mathrm{n}$.

${ }^{7}$ Pa. Stat. 1718; 3 STATUTES AT LARGE (Busch, 1896) c. 36, p. 199 (common law of England, but not the statutes); Pa. Acts of March, 1777, p. 4 (Act of the province and "common law and such statutes of England as have heretofore been in force.") See 1 KENT's CoMMENTARIEs (Holmes 12th ed. 1873) *473 n.

${ }^{8}$ Va. Acts 1789 , c. 17, p. $11 ; i d .1791$, c. 15, p. 10; id. 1792, p. 117; VA. Statutes AT LARGE (Henning 1821) c. 5, p. 127.

${ }^{9}$ ChaRTER AND Acts of RHode Istand (Rider's Reprint 1895) p. 45 ; sec also $1 \mathrm{KENT}$ 's Commentaries (Holmes 12th ed. 1873) $* 473 \mathrm{n}$.

${ }^{10} \mathrm{By}$ an act of 1712 , South Carolina adopted the English common law and a number of statutes including the Statute of Anne. 2 S.C. Statutes AT Large (Cooper's ed. 1836) 401 et seq.

${ }^{11}$ See U.S. v. Worrall, 2 Dall. 384, 394 (U. S. 1798); 1 SwiFt, A Systear of LAWS OF CONNECTICUT (1796) 42 et seq.

${ }^{12}$ MASS. Const. (1781) c. 6 , art. 6

${ }_{13}$ N. H. Const. (1784). 4 AMmerican Charters and Constitutions (House Documents, Vol. 90, 59th Cong., 2d Series, 1909) 2469.

${ }^{24}$ Laws of Northwest Territory 1788-1800, 1 Pease 253.

${ }^{15}$ For example, see Laws of Territory of Illinois (1 Pope, 1815) p. 34 ; Laws of Illinois 1819, p. 3; for Ohio and Indiana sec 1 KenT's Commentaries (Holmes 12th ed. 1873) $* 473 \mathrm{n}$.

${ }_{16}$ Vermont Statutes 1787, p. 30; Act of 1797, VerMont Revised Laws (17971808 ; ; see also 1 KENT's CoMMMENTARIES (Holmes 12th ed. 1873) $* 473 \mathrm{n}$.

${ }_{1 \pi}$ For example, on Arkansas see Small v. Strong, 2 Ark. 198, 206 (1840) ; on Indiana, Mississippi, Missouri, Ohio, see 1 Kent's Commentaries (Holmes 12th ed. 1873) *473 n. 
year of the reign of James I, 160\%, which marked the founding of Jamestown. ${ }^{18}$ The territory covered by the Louisiana Purchase theoretically inherited the civil law system, ${ }^{19}$ but many of the states which later grew out of this territory specifically adopted the common law. ${ }^{20}$ In addition to the fact that many states formally adopted the common law, the English law was also influential because, with the exception of Connecticut, ${ }^{21}$ there were no treatises on local law. Reports of local cases were neglected and many of the statutes were not printed until much later. English cases and treatises seemed to have been available all over the colonies and were the chief sources to which the new American bar could turn for authoritative statements of the law. ${ }^{22}$ Under these conditions, both the courts and the bar easily fell under the influence of the King's Court.

In the light of these facts one might expect that the common law would naturally become the basic law of each state and that after a temporary set-back of its commercial traditions each would adopt the English system, developing its law parallel to the English pattern and looking to the courts of the mother country for guidance. Such has been the accepted theory of legal history in other fields; but the law of Negotiable Paper requires closer scrutiny.

It should be remembered that at the founding of the colonies, both assignment and negotiation were unknown to the common law of England and that by the time of the Revolution, such law on the subject of negotiable paper as existed in England was almost wholly statutory, having been forced upon a reluctant bench and bar by Parliament under the pressure of the commercial community. Foreign bills of exchange were the only commercial paper accorded complete negotiability by the courts of England; bank notes, notes and perhaps inland bills were regarded as beyond the pale. If, then, the colonies adopted only the common law of England, they got little law of negotiable paper and no

${ }^{1 s}$ On Arkansas see Small v. Strong, 2 Ark. 198, 206 (1840) ; Laws of Northwest Territory 1788-1800, 1 Pease 253 : Act of 1807, Laws of Territory of Illinois (1 Pope, 1815) p. 34, Laws of Illinois 1819, p. 3 ; on Ohio and Virginia see 1 Kent's Commentaries (Holmes 12th ed. 1873) $* 473$ n.; 9 Va. Statutes at Large (Henning 1821) c. V, p. 127.

${ }^{10}$ Colvin, The Path of the Civil Law in United States, MÉmorrIes DE L'ACAdÉMIe IntERnationale de DroIt comparé, Tome 2, 108, 116, 173.

${ }^{\mathfrak{0}}$ For example, Arkansas, Missouri, Mississippi. See 1 Kent's Commentaries (Holmes 12th ed. 1873) $* 473 \mathrm{n}$.

${ }^{1}$ Swift, A System of Laws of Connecticut appeared in 1796.

= See James, $A$ List of Treatises Printed in the British Colonies and American States before 1801, HaRVARD LEGAI Essays (1934) 159. Among these were four texts on Bills of Exchange: Loveless Third English Edition, Tisdall (an Irishman), Kyd (of the Middle Temple) from Third London Edition, and also a second American Edition of the same work; see James op. cit. supra at 185, 205, 210, 211. 
recognition of simple assignment. ${ }^{23}$ However, if they also inherited the Bank of England Act, which they clearly did not,24 and the Statute of Anne, which in some cases they did, then they had the elements of the law of negotiable paper, but in a much more primitive and antiquated form than the rules which had been in effect under the colonial statutes for a hundred years.

Another alternative was that the new world might adopt the English common law and treat the cases interpreting the English statutes authorizing negotiable paper as evidence of the common law. This, of course, should be recognized as bad legal theory, but it was the practice followed in some quarters.

Massachusetts was the leading state which fell into this error. Under its constitution it did not adopt the common law, but specifically preserved the law as it had existed in the colonies. ${ }^{25}$ In the field of negotiable paper at least, it was fully equipped with a system of law far superior to that of England; but while the English source material was easily available, Massachusetts lacked the means to inform its bench and bar of, its own law. So, strange as it may seem, this state that had led the colonies and the whole English world in the recognition of assignment and the development of negotiable paper fell under the influence of this type of hybrid English common law. Without adopting any of the English statutes, it came completely under the spell of the English cases. Although the assignment statute remained on the books at least until $1814,{ }^{26}$ the courts ignorantly doubted that assignment was possible ${ }^{2 \tau}$ without a deed, and held that instruments payable in goods

Beutel, The Development of Negotiable Instruments in Early English Law (1938) 51 HARv. L. REv. 813.

${ }_{24}$ The courts of the time are in great confusion as to what English statutes were inherited by the colonies. See Bogardus v. Trinity Church, 4 Paige 178, 198 (N. Y. 1833); Boehm v. Engle, 1 Dall. 15 ( $\mathrm{Pa}$. 1767); Biddle v. Shippen, 1 Dall. 19 ( $\mathrm{Pa}$. 1773) ; Morris' Lessee v. Vanderen, 1 Dall. 64, 67 (Pa. 1782); Commonwealth v. Knowiton, 2 Tyng 530, 534 (Mass. 1807); Town of Pawlet v. Clark, 9 Cranch 292, 333 (U. S. 1815); Sackett v. Sackett, 8 Pick. 309, 317 (Mass. 1829), and authorities there cited. It is clear that they inherited all statutes specifically reenacted; it is also arguable that where there was a blanket enactment of the common law and British statutes to a certain date, all statutes applicable to the colonies were also included; but in no case were statutes not applicable included. It is clear that the Bank of England Act was not applicable to the colonies. In cases where the English statutes, such as the Statute of Anne, were contra to or covered the same field as colonial statutes, such as the Massachusetts assignment statute, there is a difficult problem of overlapping statutes which is discussed infra.

${ }^{25}$ See Reinsce, Early Englis (1899) 18 et seq.; Morris, Studies iN teE History of AMerican Law (1930) 10 et seq. The latter brands as ignorance the theory that the common law of England was adopted. Contra: Kent's Commentaries (Holmes 12th ed. 1873) *472; cf. MASS. Const. (1781) c. 6, art. 6.

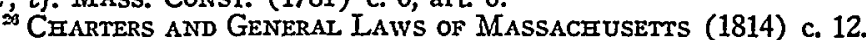

${ }^{2 \pi}$ See Perkins v. Parker, 1 Tyng 117, 123 (Mass. 1804). 
were not negotiable. ${ }^{28}$ Only on the question of negotiability of promissory notes was the colonial law able to hold its own. It is clear that the Statute of Anne was not adopted in Massachusetts. But although the courts realized this, ${ }^{29}$ without knowing why they did so, they continued to regard promissory notes as negotiable, and to treat them as if the statute had been passed. ${ }^{30}$ One commentator ${ }^{31}$ called it "sheer ignorance of the law," but it was really only the intelligent survival of the colonial system of commercial law, which was soon forgotten in the welter of cases relying upon English authorities. Thereafter, the English and post-revolutionary cases became the basis of the slow development of a Massachusetts common law of negotiable instruments on the pattern of the English system.

Mr. Justice Story writing his great treatises on bills and promissory notes in 1843 assumed that the Massachusetts pattern of the English system was the common law of the United States $\mathbf{; 2}^{32}$ and his successors, including Dean Ames of Harvard, and most teachers of bills and notes have fallen into the same error. ${ }^{33}$ It should be noted that Massachusetts, far from being typical, is almost unique in its experience. Many of the states in adopting the English common law started from entirely different premises which varied with the nature of the adopting act, and the time chosen as the date of adoption.

There was a vast change in the English common law's attitude toward commercial paper during the time from the founding of the colonies until the Revolution. The period opened with complete ignorance of and hostility to the law merchant, and closed under the influence of 1808)

2 Clark v. King, 2 Tyng 524 (Mass. 1807) ; Jones v. Fales, 4 Tyng 245 (Mass. See Jones v. Fales, 4 Tyng 245, 254 (Mass. 1808), stating flatly that the Statute of Anne was not adopted; of. Coolidge v. Ruggles, 15 Tyng 387 (Mass. 1819).

${ }^{\circ}$ Rice v. Stearns, 3 Tyng 225 (Mass. 1807); see also Blake v. Sewell, 3 Tyng 556 (Mass. 1799); Putnam v. Sullivan, 4 Tyng 45 (Mass. 1808). It should be noted that these cases show litigation only on advanced questions of negotiability; the elementary points, such as the right of a holder to sue and cut off defense, had been settled in early colonial times.

s1 Rand, in 4 Tyng 254, note (c) (Mass., 1865 ed.).

3 See Story on Bills of Exchange (1843) vii; Story on Promissory Notes (1845) 9, where he assumes that the English common law governs and that the Statute of Anne was either adopted or regarded as part of the common law.

${ }^{3}$ ANIES' CASES ON BILLS AND NoTES, published in 1881, contains a few more than seven hundred cases. Of these over five hnndred are English, over four hundred of which were decided after the Revolution; and could not, therefore, have any direct effect on the American law at that time. Each chapter is a development of the English cases. The American cases, of which there are less than two hundred, half of which came from Massachusetts and New York, appear at the ends of the various divisions, and then they are used mostly to illustrate anomalous variations from the English common law. The three most popular case books in the field still use the same plan with a larger sprinkling of American cases and occasional references to the N. I. L. 
Lord Mansfield who was extremely friendly to the mercantile point of view. During this time there were also passed a number of English enabling statutes which were used as a lever by Lord Mansfield to effect this change of attitude. Chief and most influential among these was the Statute of Anne, passed in 1704. ${ }^{34}$ So far as the law of negotiable instruments was concerned, the date of adoption of the English common law, and the question of whether or not the English statutes were also adopted was vital in determining the nature of the basic law of the - state in question. The state which adopted only the common law got one system. Those which adopted the common law and statutes inherited quite another, and the date of adoption was also variable, affecting both of these factors. The mathematical possibilities are legion and so were the actual adaptations.

New York took upon itself the most complete system, vis., the common law and statutes of England and all the colonial acts as of 1775.35 In Maryland, which adopted the common law as of $17 \% 4$, the Statute of Anne was regarded as a common law statute, ${ }^{36}$ but in North Carolina, which adopted the common law in 1778, it was not so treated..$^{37}$ South Carolina and Rhode Island had adopted the English common law as of the first quarter of the eighteenth century, the former specifically enacting the Statute of Anne, ${ }^{38}$ the latter refusing to do so even after the Revolution..$^{39}$

States like New Jersey, Pennsylvania, Vermont, Missouri and Mississippi which adopted the English common law as of dates later than the Statute of Anne might have adopted it; ${ }^{40}$ but in many of these states,

${ }^{24}$ For a discussion of this statutory development, see Beutel The Dcvelopment of Negotiable Instruments in Early English Law (1938) 51 Harv. L. Rev. 813, 841 et seq.

${ }^{3}$ See note 2 supra. The colonial acts and laws being far ahead of England, New York had a system all its own. New York specifically adopted statutes modelled after the Statute of Anne during the colonial regime in 1770 and again in 1773. 5 CoLONIAL LAWS OF NEW YoRK (1804) cc. 1428, 1612, 63, 545. In 1767, in Duryee v. Hopkins [Morris, Select Cases of the Mayors Court of New YoRk, 1674-1784 (1935) 523] the New York court allows a holder to sue on a note, alleging the statute which may be either the English Statute of Anne or the earlier New York assignment statute. Other New York colonial cases also referred to the statute. See Beutel, Colonial Sources of Negotiable Instrumcnts Law of the United States, (1939) 34 IrL. L. Rev. 137, 147, n. 96.

${ }^{36}$ See Md. Declaration of Rights and Const. (1776); 2 Alexander, British Statutes in Force in Maryland (Baldwin's 2d ed. 1912) 883 et scq.; Keliy, ENGLish Statutes in Force in Maryland (1811) 268.

${ }^{7}$ See note 6 supra; Martin, Collection of English Statutes of North

Carolina (1792) does not include the Statute of Anne.

$\approx$ In 1712. 2 S. C. StatuTES AT LARGE (Cooper 1836) 401 et seq.

$\Rightarrow$ See note 9 supra. This adoption was as of 1700 . After the revolution the Statute of Anne was adopted in a form that made notes non-negotiable. Laws of Rhode Island 1798, p. $446, \S 3$. But this limitation was later removed. Laws of Rhode Island 1822, p. 355 .

${ }^{40}$ See notes $3,7,16,20$ supra. 
such as Georgia, there was no need to raise the question because other state statutes were adopted which were controlling. ${ }^{41}$

It seems clear that Virginia, Illinois, Ohio, ${ }^{42}$ and many other states $^{43}$ which started from an entirely different premise by adopting the English law as of the fourth year of the reign of James I, 1607, did not receive the statute of Anne.44 In fact at this time there was no English common law of negotiable instruments, nor were there any specific statutes incorporating any part of the law merchant into the law administered by the King's Courts. ${ }^{45}$ So in the field of commercial paper, these states were either without law on the subject; or had to look elsewhere than to the common law of England for the rules of commercial transactions. It can thus be readily seen that even in those states which purported to adopt the common law of England, there were a whole series of individual common laws, each differing radically from the others.

\section{The Law Merchant}

During the fourth year of the reign of James I and for at least one hundred years thereafter, the courts of England recognized that the Law Merchant was a separate system, administered by separate tribunals. It is not at all surprising to find this theory at work in the new states of the United States. Following the English staple traditions, both Georgia ${ }^{46}$ and North Carolina ${ }^{47}$ set up a system of merchant courts which lasted until long after the Revolution and administered the law merchant as a separate system. North and South Carolina also continued the courts of Pie Powder.48

The extent of the development of the law merchant in these sep-

4 Digest of Laws of Georgia 1775-1800, p. 424; id. (1792) at p. 488; id. (1797) at p. $627 ; i d .(1799)$ at p. 698.

See note 18 supra.

$\checkmark$ Aniong these might be classed such states as Indiana, West Virginia, Michigan, Kentucky and many others which derived their law directly fron Virginia or the Northwest Territory. See Riedman v. Macht, 98 Ind. App. 124, 127, 183 N. E. 807,808 (1934) and authorities there cited.

4 One writer has gone so far as to say that this view is supported by the weight of authority. See Note (1932) 31 MICH. L. REv. 273. But this is a highly doubt-

ful statement in light of the fact that so many local statutory factors intervened. (1938) 51 HARV. L. REV. 813, 838.

${ }^{43}$ See Digest of Laws of Grorgia $1775-1800$, p. 90 (1763); id. at p. 540 (1794); GA. Const. (1789) Art. III, § 3.

Acts of North Carolina 1784, c. 25, p. 41.

Acts of North Carolina 1802 , c. 31 , p. $21 ; 3$ S. C. Statutes AT Large (Cooper 1836) pp. 205, 215, $218(1723) ; 4$ id. at p. 558 (1783); 4 id. at 650 (1784); 4 id. at 653 (1785). A number of other colonies had such courts, but it is not clear whether or not they survived after the Revolution. See Bond, InTroducrion, ProCEEDINGS OF MARYLAND Court of Appeals 1695-1729 (1933) p. xii; 1 Colonial LAWS OF NEW YORK (1896) c. 26, p. 298 (passed in 1692). 
arate courts must be left to the legal historians; but it should be noted that in theory at least, if not in fact, the law merchant, in some of the states, continued as a separate system of law outside of and different from the common law (whatever that was) down to the time of the adoption of the Negotiable Instruments Law. ${ }^{49}$ It was so recognized in section 196 of the Uniform Laws; and we have tangible evidence that at least some of the framers of the act $t^{50}$ were not laboring under the illusion of the draftsmen of the later uniform acts, ${ }^{51}$ that the law merchant was part of the common law.

It is not possible here to point out in detail the ultimate result of this doctrine of separability of the law merchant; but it suffices to say that it had an important effect on decision in some states, while in others it was probably entirely ignored. ${ }^{62}$

\section{Hostility to English Law}

Another important influence against uniformity was the growing hostility to English law which lasted late into the nineteenth century. Shortly after the Revolution a number of states specifically repealed all British statutes ${ }^{53}$ which of course included the Statute of Anne and others facilitating the development of the law of negotiable paper. The commercial community undoubtedly resented the antiquated doctrines of the common law, and the political feeling ran high against England. These two tendencies resulted in non-citation statutes in Pennsylvania, ${ }^{54}$ Kentucky $y^{55}$ and New Jersey ${ }^{56}$ which forbade the courts to take notice of English common law, English cases, or any compilation, commentary, digest, lectures, treatise, or other explanations of the

\footnotetext{
${ }^{43}$ For examples of common statutory recognition of this distinction see the following sections of the compilations cited infra note 94: Alabama, $\$ 869$; Illinois, \$ 7, p. 2796; Iowa, \$\$ 3043, 3050; Michigan, \$ 1577; Nevada, \$2747; New Mexico, $\S 2545$; New York, $\$ 1$, p. 278; Óregon, \$ 3188; Rhode Island, \$7, p. 494; Tennessee, §2713; Washington, § 2192; Wisconsin, §1675. Judicial recognition of the difference is so well known that citations are unnecessary. See also, MECHEN oN CoRPORATIONS (1908) $\$ 1740$ A

${ }^{\infty}$ Eaton, Decisions on the Negotiable Instruments Act (1913) 12 MicH. L. REv. 89, 101. See also Crawford, Negotiable InStruarents Law (1st ed. 1897) 7.

"It should be noted that the N.I.L., § 196, says: "In cases not provided for in this act the rules of the law merchant shall govern." Other and later uniform acts read "the rules of law and equity including the law merchant." For example, see UNIFORM SALES ACT \$ 73; UNIFORM WAREHOUSE RECEIPTS ACT \$ 56; UNIFORM STOCK TRANSFER Act $\$ 18$; UNIFORM BILLS OF LADING ACT $\$ 51$.

${ }^{53}$ See McCloskey, The Constitutionality of Section 196 of the Louisiana Negotiable Instruments Lawe (1933) 8 TULANE L. REv. 127, 135.

$\approx 1$ LAwS OF NEW YoRR 1783-1801, Act of March 30, 1801, c. 90, § 28, p. 358; Laws of New Jersey 1799 (Patterson) p. 436; Acts of Virginia 1792, p. 117.

Acts of Pennsylvania 1810, c. 98, p. 136.

${ }^{65}$ Acts of Kentucky 1807, p. 23 (approved Feb. 12, 1808).

${ }^{2 s}$ Laws of New Jersey 17999 (Paterson) p. 436.
} 
common law since July 4, 17\%6. Tennessee ${ }^{57}$ even went so far as to pass a statute abrogating the law merchant because it was part of the common law. These statutes were not only a passing phase of popular resentment; there is good evidence that they were recognized and followed by the courts. ${ }^{58}$ Under these circumstances some states were forced, so far as the law of negotiable paper was concerned, to rely upon local customs, colonial statutes, and state statutes which soon appeared in abundance, and in ever widening variation.

\section{The Banking Statutes}

The first important post-revolutionary statutes affecting negotiable paper were those growing out of the banking and credit situations. Both before and after the revolution, the colonies were flooded with bills of credit issued to pay for various wars. As indicated elsewhere these bills were fully negotiable, but circulated at a tremendous discount..$^{59}$ In order to bolster up their credit systems, the various states immediately after the revolution began to create state banks with circulating privileges.

Among the first to take this step was Connecticut with the creation of the banks of Hartford, New Haven and New London in 1792.60 It was soon followed by other states. These banks at first were chartered by individual statutes which created a number of types of negotiable paper. Notes and bills obligatory of the banks themselves, ${ }^{61}$ bonds issued by the banks, ${ }^{62}$ notes and drafts payable at the bank ${ }^{63}$ were among the commercial instruments made negotiable by these acts. Later on the statutes in a more general form covering all banks and paper payable at banks were adopted by many states. ${ }^{64}$

To protect the banks in the privilege of circulation, many states

${ }^{\pi}$ Tenn. Laws 1812 , c. 72 , p. 79.

$\approx$ See Chestnut Hill and Spring House Turnpike Co. v. Rutter, 4 S. \& R. 6, 18 (Pa. 1818); Hickman v. Boffman, Hardin's Rep. 348, 365 (Ky. 1808); Gallatin v. Bradford, Hardin's Rep. 365, 372 n. (Ky. 1808).

Beutel, Colonial Sources of the Negotiable Instruments Law of the United States (1939) 34 IrL. L. REv. 137, 139 et seq.

${ }^{\infty}$ Conn. Laws 1796 (Hudson and Goodwin's ed.) pp. 42, 47, 52. See also the provision for the Middletown bank of 1795. Conn. Laws of 1796 (Hudson and Goodwin's ed.) p. 45 .

${ }^{1}$ Conn. Laws 1809 , c. 1 , p. 19 (bills and notes of rine Derby bank made negotiable); Digest of Laws of Maryland (1799) pp. 79-80; Digest of Laws of South Carolina (James 1822) p. 60.

${ }^{\circ}$ Digest OF LAwS OF MARYLAND (1799) p. 83 (bonds and bills and notes of Bank of Maryland made negotiable); id. at p. 86 (identical provisions for the Bank of Columbia).

$\infty$ Conn. Laws of 1796 (Hudson and Goodwin's ed.) p. 42; see also Miller v. Riley, 12 Conn. 523 (1797).

claws of Indiana 1818, p. 232; Acts of Kentucky 1806, pp. 20-21; Digest of Laws of Soutr Carolina (James, 1822) p. 60 ; Acts of Virgima 1804, $\$ 14$. 
prohibited the issue of private bills of credit, ${ }^{65}$ and promissory notes below certain denominations. ${ }^{66}$ Others prohibited private bills of credit but authorized promissory notes. ${ }^{67}$ In still others, promissory notes were not recognized as negotiable unless payable at banks. ${ }^{68}$ These statutes continued to multiply and spread down to the adoption of the Negotiable Instruments Law. In fact, this rule was applied in an Indiana case ${ }^{69}$ as late as 1934 .

\section{The Colonial Assignment Statutes and Statutes Enforcing Colonial Customs}

The adoption of the antiquated common law by some state legislatures or courts and the anti-citation statutes in others created a demand in the commercial community for the clarification of the law of commercial paper. The result of this pressure was the adoption of numerous statutes regulating the assignment and negotiation of commercial paper. The most popular of these was the old Massachusetts statute of assignments, ${ }^{70}$ adopted in various forms all over the United States, which gave the assignee the right to sue, usually in his own name, either with or without the right to cut off defenses. ${ }^{71}$ The English statute of Anne was adopted in some states, but in many others it never appeared, since the necessity for it had disappeared with the adoption of a variation of the Massachusetts statute which was much wider in scope.

${ }^{65}$ The later colonial statutes are full of prohibitions of this kind, many of which undoubtedly were carried on into statehood. For an example of such statutes scc Conn. State Laws 1821, tit. 70, p. 360 ; id. at c. 2, pp. 66, 68, 71, 73, 75, 77, 79, 83, 85,89 .

${ }_{\text {os }}$ Laws of Connecticut 1811, c. 8, p. 73; Conn. State Laws 1821, tit. 70, p. 360.

$\because 9$ Va. Statutes at LARGe (Henning, 1821) c. 24, p. 431 (1777).

${ }^{2}$ Private banknotes made illegal. 12 VA. StatuTes at LARGE (Henning, 1823) c. 68, pp. 166-167 (1779). See also BranNaN's NegotiabLe InstruneNTS LAw (Beutel's 6th ed. 1938) 1120.

${ }_{63}$ Riedman v. Macht, 98 Ind. App. 124, 183 N. E. 807, 808 (1934). Scc the additional Indiana cases cited in BranNAN'S Negotiable INSTRUNENTS LAW (Beutel's 6th ed. 1938) 1120.

${ }^{70}$ The original statute passed in 1647 read as follows: "It is ordered by the Authority of this Court that any debt, or debts due upon bill, or other specialtie assigned to another; shall be as good a debt \& estate to the Assignee as it was to the Assigner at the time of its assignation. And that it shall be lawful for the sayd Assignee to sue for and recover the said debt, due upon bill, and so assigned, as fully as the originall creditor might have done, provided the said assignment be made upon the backside of the bill or specialtie." See THE LAW AND LiBErTIES OF MASSACHUSETTS 1648 (Huntington Reprint 1929) 4; cf., THE CHARACTERS AND' General Laws of Massachusetts (1814) c. XII, 52; Brigham, Plymouth Colony Laws (1836) 200; Colonial Laws of MASSAChuSETTS (1887) 10; CoLONIAL LAwS OF MASSACHUSETTS 1660-1672 (1889) 25. For the history of the sporead of this statute in colonial times, see Beutel, Colonial Sources of the Ncgotiable Instruments Law of the United States (1939) 34 ILL. L. REv. 137, 141-142.

The law was still indentifiable in the statute law of fourteen states at the adoption of the N.I. L. See Beutel, Colonial Sources of the Negotiablc Instriments Lare of the United States (1939) 34 ILL. L. REv. 137, 142, n. 43. 
New York, which adopted the common law by its constitution, also specifically included the colonial statutes. ${ }^{72}$ Among these was both the Massachusetts assignment statute allowing an assignee to sue in his own name, ${ }^{73}$ and also the Statute of Anne which was later re-enacted in 1794 and $1801 . .^{74}$ It is doubtful therefore whether the English common law system of negotiable paper ever prevailed in New York. Pennsylvania, another leading commercial state of the time, had followed Massachusetts during colonial times ${ }^{75}$ and at the revolution sanctioned both assignment and negotiation of bonds as well as simpler forms of commercial paper. ${ }^{76}$ Under the influence of the common law the courts temporarily reversed their trend $;^{77}$ but later, probably because of the anti-citation statutes, the reversing cases were themselves reversed. ${ }^{78}$ In the meantime, however, by statutory enactment the state acquired the Philadelphia note which was negotiable if payable in that city "without setoff or without defalcation."79 New Jersey adopted both an assignment statute ${ }^{80}$ and also the Statute of Anne, but the latter ${ }^{81}$ specifically provided that notes should be non-negotiable unless, like the Philadelphia notes, they contained the words "without defalcation or discount." Although this is no longer necessary, it still appears occasionally on printed forms in widely scattered parts of the country. Virginia, as in colonial days, continued to struggle with the problem of assignment and negotiation, constantly fluctuating between the colonial law and the English common law. ${ }^{82}$

${ }^{72}$ See note 2 supra. See also 1 Kent's Commentaries (Holmes 12th Ed. 1873) $* 473 \mathrm{n}$.

1 LAWS OF THE COLONY OF NEW YORK (1896) c. 13, p. 153, adopted in 1684

"Statutes modelled after the Statute of Anne were adopted in 1770 and 1773,5 Colonial Laws of NEw York (1844) cc. 1428, 1612, pp. 63, 545. After the revolution it was reenacted twice, LAws of NEW YoRK 1783-1801, p. 229; cf. also Laws. of New York 1783, c. 33, p. 54, and Laws of New York 1794, c. 48, p. 26.

${ }^{75}$ See Blatrinn, DuKe of YorR's Book of Laws, 1676-1682 (1876) 12, 146, 210-11; Laws of Pennsylvania, 1700-1775, c. 193, pp. 77-78, adopted in 1715.

io See note in 1 Cranch 367, 457 (U. S. 1804); Robertson v. Vogle, 1 Dall. 252, 255 (Pa. 1788).

"M'Cullough v. Houston, 1 Dall. 441 (Pa. 1789); Cummings v. Lynn, 1 Dall. 444 ( $\mathrm{Pa} .1789)$.

Bullock v. Wilcox, 7 Watts 328 (Pa. 1838).

"See Brigetity, Digest of Laws of PeNnSYLVANia (1869) $\S 1$. This act was passed in 1797. See also 1 Dall. $444 \mathrm{n}$. (Pa. 1789).

${ }^{80}$ Laws of New Jersey 1797 (Paterson), p. 254.

${ }^{81}$ Laws of New Jersey 1799 (Paterson), pp. 341-342. This statute also provided that inland bills of exchange for over eight dollars should enjoy the same status as foreign bills.

For the colonial history see Beutel, Colonial Sources of the Negotiable Instruments Law of the United States (1939) 34 ILL. L. REv. 137, 150. After the Revolution in 1776, as indicated in note 18 supra, the state adopted the common law and statutes of England as of 1607 . In 1779 and 1786 the assignment statute was again passed giving the assignee the right to sue in his own name subject to discounts available before the assignment. Acts of Virginia 1786, c. 73, p. $42 ; 12$ VA. StatuTES AT LARGE (Henning 1823) c. 68, pp. 358-359. Under the statute 
The Northwest Territory not only clearly adopted the Massachusetts assignment statute, but also made inland bills assignable only. ${ }^{83}$ This statute was later adopted in many of the states which were carved out of that territory.84 By a variation in this statute adopting the almost universal colonial custom, ${ }^{85}$ bonds, notes and instruments payable in money or chattels were made negotiable. 80 This law, like the other, spread to many states, ${ }^{87}$ and instruments payable in chattels are still negotiable in at least Illinois and Georgia, by specific amendment to the Negotiable Instruments Law.88

The most sweeping of all these post-revolutionary statutes was adopted in Georgia in 1790. It made all bonds and other specialities, all promissory notes and liquidated demands for money or specific articles fully negotiable by indorsement thereon. No formal requisites were mentioned, but the parties, if they desired, could restrict negotiability by clearly indicating their intention to do so. ${ }^{80}$ Here is complete negotiability with the presumption that all such contracts are negotiable in the absence of clearly expressed intention to the contrary.

it was held in Overstreet v. Randolph, Wythe 47 (Va. 1789), that a bond was negotiable to cut off the defense of fraud. In 1789 all English statutes prior to the fourth year of the reign of James I were repealed. Acts of Virginia 1789, c. 17, p. 11. But this statute was suspended by the Virginia Act of 1791, c. 20, p. 10 , declaring the common law and the English statutes to be in force. This in turn was repealed in so far as it put the English statutes in force, leaving the conmion law to supply the rules of decision. Following this statute, Overstrect v. Randolph, supra, was overruled and the common law was applied to both negotiation and assignment. Morton v. Rose, 2 Wash. 233 (Va. I796); and sec the note in Wythe (Va.) 433. In the Act of $1804, \S 14$, notes payable at banks were made negotiable, and in 1807 the assignment statute was again passed but it now preserved defenses. Finally in 1818 the law was reduced to a code of seven sections. Virginia Acts 1818, c. 52 , pp. 72 et seq.

\& Laws of Northwest Territory 1788-1800, 1 Pease 360, adopted in 1799.

84 Act of 1807, Laws of the Territory of Illinois (1 Pope, 1815) p. 48. Laws of Indiana Territory 1805 , c. 8 , p. 6 ; Act of Feb. 21, 1805, 3 Acts of Ohio; repealed by Act of June 25, 1810, 8 Acts of Ohio, p. 69 .

${ }^{8}$ See Beutel, Colonial Sources of the Negotiable Instruments Law of the United States (1939) 34 ILL. I. REv. 137, 142-145.

${ }^{8 s}$ Laws of Illinois 1819 , p. 3; Laws of Indiana Territory 1805, c. 8, p. $6 ; 8$ Acts of Ohio, p. 69; repealed as to chattels by Act of February 25, 1820, 18 Acts of Ohio, p. 163.

ST Colo. ANn. Stat. (Mills, 1871) §\$243, 244; GA. Code (1892) §3682; IrL.

Stat. Ann. (Starr and Curtis 1896) 2782, § 3, 2789, §4; Iowa Code AnN. (1897)

\$ 3045. Cf. ArK. Dig. Stat. (1894) §489; IND. Stat. ANN. (Burns, 1894) §§ 5012, 7515; see Culp, Negotiability of Promissory Notes Payable in Spccifics (1937) 9 Miss. I. J. 277, and additional authorities there cited.

${ }^{3}$ See Brannan's Negotiable Instruments LAw (Beutel's 6th ed. 1938) 2, 90 , notes. This of course does not include full negotiability given to documents of title which is much wider; see Beuter, Bank OfFICER's HANDBOoK of CoMmercial BANKING LAW (1939) 73 et seq.

${ }^{2}$ Act of 1790 , Digest of Laws of Georgia $1775-1800$, p. 424 ; Act of 1792 , p. 488; Act of 1797, p. 627; Act of 1799, p. 698. 
This rule has been incorporated into the modern Uniform Laws governing bills of lading and warehouse receipts. ${ }^{90}$

No particular purpose would be served by tracing further the development of the statutes in each state, or following particular lines of decisions. It suffices to say that although the interpretation placed by the courts upon the statutes were sometimes more varied than the statutes themselves, many of the apparent inconsistencies in the holdings of the courts of particular states can easily be explained if they are considered in the light of the statutes then current.91

As the nation expanded westward with the admission of each state or territory, a new set of statutes following one of the old types or introducing new variations appeared. The net result was that the statutes grew and increased like weeds in all the forty-eight states and territories which constituted the continental United States at the time the American Bar Association recommended the adoption of the N. I. L.

\section{State Statutes at the Time of the Recommendation} OF THE N. I. L.

When Judge Brewster, in 1898, told the American Bar Association that the N. I. L., if adopted, would reduce "the pre-existing statutory law on the subject by hundreds of pages," he spoke with admirable restraint..$^{92}$ At the time the Commission on Uniform Laws approved Crawford's draft of the act for final adoption, every state, and the territories which later became states in the union, had one or more statutes attempting to regulate in whole, or in part, the law of commercial paper. These statutes, ranging from a few simple provisions on attorney's fees, the right of an assignee to sue, and the effect of holidays on maturity in Florida, ${ }^{83}$ to a complete codification of the subject in the state of California, covered all the material now found in the N. I. L. and a great deal more.

The remainder of this article will be devoted to a brief discussion of these statutes, pointing out some of their salient features, and their effect on the general laws in the field. For convenience, the compilations set out in the margin have been used as a basis of comparison, and unless otherwise stated, citations refer to sections and pages in the source book named for the particular state involved.94

\footnotetext{
$\$ 8$.

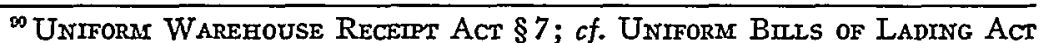
${ }^{21}$ For an example of such an explanation of the Virginia cases see note 82 supra.

(1898) 21 A. B. A. Rep. 315, 323; reprinted in Beutel, Materials AND Cases on Negotiable Paper (1936) 5, 9.

${ }^{\circledR}$ Fla. Laws 1895, p. 139 ; Fla. REv. ŚTAT. (1892) 1073, 2315, 2316.

os Alabama, Ala. Code (1897); Arizona, ARIz. Rev. Stat. (1887); Arkansas, ARr. Dig. Stat. (1894); California, Cal. Civ. Code (Deering, 1897); Colorado,
} 
It is obviously impossible, and it would serve no useful purpose here, to treat separately the sections of each statute and the judicial interpretations placed upon them by the various courts. Only the more important features of the acts will be explained. First the complete codification will be noted. Then certain groups of similar sections in the various statutes and codes will be compared with corresponding requirements in the present statute.

States in which the Law of Negotiable Instruments was Alrcady Codified

California, under the influence of the Field codes of the latter part of the nineteenth century, became a leader in the movement for the codification of the common law. ${ }^{95}$ When the California Codes were adopted, in 1872, the commissioners recommended a complete code on negotiable instruments of one hundred and seventeen sections, ${ }^{90}$ copied almost verbatim from Field's code proposed for New York. ${ }^{07}$ This portion of the California Civil Code was a codification of the law of negotiable instruments, covering bills of exchange, promissory notes, bank notes, checks, bonds, and certificates of deposit;08 it rivals in

Colo. Ann. Stat. (Mills, 1891) ; Connecticut, Conn. Gen. Stat. (1888); Delaware, Dex. Rev. Stat. (1893); Florida, Fla. Rev. Stat. (1892); Georgia, Ga. Code (1895); Idaho, IdAho Crv. Code (1901); Illinois, ILL. Stat. ANN. (Starr \& Curtis, 1896); Indiana, INd. STAT. ANN. (Burns, 1894); Iowa, Iowa Code ANN. (1897) ; Kansas, Kan. GEN. STAT. (1897, vol. 2); Kentucky, IKY. STAT. (1894) ; Louisiana, LA. REv. Laws (1896), also Voorhies Rev. Crv. Code (Saunders, 1889), and Garland's Rev. Code of Practice (Woolff, 1901); Maine, ME. REv. Stat. (1883) ; Maryland, Mp. Code Pub. GEN. LAws (1888); Massachusetts, Mass. Pub. STat. (1882); Michigan, Mich. Gen. Stat. (Howell, 1883), also Mich. Gen. Stat. (Howell, 1883-1889); Minnesota, MiNn. Gen. STAt. (1894); Mississippi, Mrss. Cond ANN. (1892); Missouri, Mo. Rev. Stat. (1889); Montana, Mont. Comp. Stat. (1888); Nebraska, NEb. Comp. Stat. (1895) ; Nevada, Nev. Comp. Laws (1861-1900); New Hampshire, N. H. Pub. STAT. (1891); New Jersey, N. J. Gen. Stat. (1896); New Mexico, N. M. Comp. Laws (1897); New York, N. Y. REv. StAT. (1896) ; North Carolina, N. C. CoDE (1883) ; North Dakota, N. D. Rev. Code (1895); Ohio, OHIo Rev. Stat. ANN. (1897); Oklahoma, OKLA. Stat. (1893); Oregon, Ore. Code and Gen. Laws (Hill, 1892); Pennsylvania, PA. DiG. Laws (Brightly, 1885), also PA. Dig. Laws (1891, 1895); Rhode Island, R. I. GEN. IAwS (1896); South Carolina, S. C. Rev. STAx. (1894) ; Tennessee, TENN. CoDE (1884), also TENN. Code (Supp. 1885-1893); South Dakota, S. D. Ann. Stat. (1901); Texas, Tex. AnN. Civ. Stat. (Sayles, 1898); Utah, Üta Rev. Stat. (1898); Vermont, Vt. Stat. (1894); Virginia, VA. CoDE (1887); Washington, WASH. REV. STAT. AND CODE (1896); West Virginia, W. VA. Code ANN. (1884); Wisconsin, WIs. Stat. (1898); Wyoming, Wyo. Rev. Stat. (1899).

${ }^{\infty}$ Georgia was the first state to codify the common law in 1861 , but due to the war between the states, its code had no influence. Smith, The First Codification of the Substantive Common Law (1930) 4 TULANE I. REv. 178, 182.

${ }^{2}$ See 2 Revised Laws of CaLIForNIA (1871) tit. 15, \$\$ 3086-3262, pp. 523-

549 ; CAL. CIV. CoDE (Hart, 1876) tit. $15,16, \$ \S 3086-3268$, pp. 408-428.

${ }^{n}$ Compare the Civil Code of New York (1865) tit. 15, $\$$ 1712-1828, pp. 522-

561 , with the California codes cited supra note 96.

${ }^{\circledR}$ CAL. CIV. CODE (Hart 1876), § 3095 . 
completeness and skill of draftsmanship both the English Bills of Exchange $A c t^{99}$ and the present $N$. I. L.

Scholars, comparing the B. E. A. with the N. I. L., have often pointed out that although many of its details' are taken from the English law, its outline is entirely different and its scope is much wider. The answer to the riddle of this change in outline and scope is found in the California Civil Code. A comparison of the acts will show that the N. I. L. adopted the California outline and not that of its British model. The four titles of the N. I. L. are taken verbatim and in the same order from the six Chapter headings of the California Code. ${ }^{100}$ The only differences are that Chapters III and IV of the California Code ("III. Promissory Notes" and "IV. Checks") become Title III. ("Promissory Notes and Checks") of the N. I. L., while Chapter V. ("Bonds, Bank Notes and Certificates of Deposit") of the California Code, which in 1896 contained only one short section, ${ }^{101}$ is omitted from the outline. Nine out of fifteen of the Article headings of the N. I. L. are taken almost verbatim, and in a similar order, from the California Code.102 That the N. I. L. uses "Title" where the California Code uses "Chapter" may be accounted for by the fact that the N. I. L. was a complete act in itself while the California Act was only a part of a larger codification. But the similarity does not end with the outline. Article I of the N. I. L., which has often been criticized because it covers the whole field of negotiable instruments instead of simply limiting itself to notes and checks and bills of exchange as does the English Act, ${ }^{103}$ gains its breadth of scope directly from Article I of the California Act. The "must" sections of the N. I. L., as, for example, Section one, "An instrument to be negotiable . . . must contain an unconditional promise or order to pay a sum certain in money," find their origins in the California Section 3088, "A negotiable instrument must be made payable in money only, and without any conditions not certain of fulfillment." This same mandatory wording, not contained in the

${ }^{\infty} 45 \& 46$ VICr., c. 61 (1882), hereafter cited as the B. E. A.

${ }^{100}$ Cal. Crv. Cone (Hart, 1876) pp. 408, 418, 427, 428.

${ }^{101}$ Section 3261: "A bank note remains negotiable, even after it has been paid by the maker." Section 3626 was repealed July 1,1874 . See CAL. Civ. ConE (Hart, 1876) p. 428.

${ }_{103}$ Compare N.I. L., Title I, Articles I, III, VI, VII, and Title II, Articles I, II, III, V, VI, with CAL. CIv. CoDE (Hart, 1876), Title XX, chapter I, Articles II, III, IV, V', VII, and chapter II, Articles I, IV, III, V. Other articles of the California Code, stuch as Chapter II, Article II ("Days of grace"), are omitted because they are only one section long and are covered in part of a single section, such as N.I.L. $\$ 85$. The N.I. L. in substance of outline and continuity of material is much closer to the California Code than to the B.E. A., where a comparison of outline yields nothing but similarity of detail in certain sections.

${ }^{203}$ For example, see ChAFEE (Chafee 4th ed. 1926) 7, and the authorities there cited. 
B. E. A., is found throughout the other sections of this fundamental article in both American codes. ${ }^{104}$

Although Mr. Crawford, the draftsman of the N. I. L., had a mandate to follow the B. E. A. as much as he thought it applicable to American conditions, ${ }^{105}$ some sections of the N. I. L. are taken verbatim from the California Code ${ }^{106}$ and many others which differ from the corresponding B. E. A. provisions are in substance the same as those of California. ${ }^{107}$ It might be argued that this is a mere coincidence were it not for the fact that the commissioners' notes to the N. I. L. cite the California Code in three places and admit taking some of its material. ${ }^{108}$ The infrequent citation is probably due to the fact that the attention of the Uniform Laws Commission, at the time, was centered on the B. E. A.; consequently the commissioners' notes very naturally referred to the English Act wherever it was pertinent. It is significant, however, that as Judge Brewster points out, the B. E. A. is much nearer to the continental codes than it is to the N. I. L.100 The N. I. L., on the other hand, in its general outline and breadth of codification is nearer to the California code tban it is to the B. E. A.

The reason why the draftsmen forsook the narrow outline of the B. E. A. and followed the broader scope of codification found in California, is to be discovered in two very important and practical features of the contemporary law of the United States. The first was that the California Code had already been copied in six other states, ${ }^{110}$ so that if the new negotiable instruments law was ever to be uniformly adopted, it had to amount to more than a narrow and specific statute. Otherwise the California Code which was already spreading would be its rival, and those states which had already adopted the California model could not easily be induced to change it. The seriousness of this consideration is shown by the fact that California itself was one of the

\footnotetext{
${ }^{104}$ CAL. Civ. CodE (Hart, 1876) $\$ \$ 3088,3089,3093 ;$ N. I. L. $\$ \$ 1,1(5), 5$.

10s Brewster, (1898) 21 A. B. A. REP. 315, 320 et seq.; BEUTEL, MATERIALS AND Cases on Negotiable Paper (1936) 5, 6-7.

${ }^{103}$ For example, N.I. L. $\$ \$ 65(1), 65(2)$, and 154 are taken from $\$ 3116(1)$, $3116(2)$ and 3226 of the California Code.

${ }^{107}$ Conipare N. I. L. $\$ \S 64(1), 70,135$ with $\$ \$ 3117,3130,3197$ of the California Code. Many other close comparisons are possible where the wording of the B.E.A. is also similar. An interesting question, which cannot be answered at this writing, is thus raised. Did Judge Chalmers have the California Code or the Field Code before him when he drafted the B.E. A. in 1881?

${ }^{100}$ See Commissioners' notes to N.I. L. nos. 64, 71 and 154, in BEUTEL, MAterials ANd Cases on Negoniable Paper (Supp. 1936) 21, $24,44$.

${ }_{103}$ Brewster, loc. cit. supra note 105 ; and see CHALMrers, Bills of ExcHANGE Act (3d ed. 1887) $x 1$ et seq.

${ }^{110}$ Idaho, North Dakota, Oklahoma, South Dakota, Utah and Wyoming, in codes cited supra note 94.
} 
last states to adopt the N. I. L., ${ }^{111}$ followed only by Texas ${ }^{112}$ and Georgia. ${ }^{113}$ The second reason for adopting complete codification was equally serious: There were statutes in all the other states and these were so variously worded that any partial attempt at codification would raise more interior conflicts in the states than it would settle. ${ }^{114}$ If, then, uniformity was to be achieved at all, it was necessary for the draftsmen to depart from the B. E. A. and to codify the whole law as California had done. The significance of this departure and its effect on the meaning and interpretation of the N. I. L. must be discussed elsewhere; but it is still useful to examine a few illustrative details of the condition of the statute law in all the states which necessitated this policy.

I11 Laws of 1917 , c. 64.

112 General Laws of 1919, p: 190

${ }^{113}$ Laws of 1924 , p. 126. It is also significant that four other of the seven code states were also late in passing the N. I. L. Idaho, Laws of 1903, p. 380; Wyoming, Laws of 1905, c. 43 ; Oklahoma, Laws of 1909, c. 24 ; South Dakota, Laws of 1913,' c. 279

11i The nature of this difficulty should be the subject of a different paper. However, a few illustrations will serve to clarify the point. Many of the statutes used such terms as "bonds and other obligations under seal" (Minnesota, \$2220); "all bonds, bills, and notes" (North Carolina, \$ 41); "all promissory notes, bonds, due bills and other instruments" (Colorado, \$243). They then proceeded to nake these instruments as negotiable as bills of exchange or as promissory notes. See notes 134, 135 infra. Many states, like Califorma, included in the tern "negotiable instrunient" such instruntents as bills of exchange, pronissory notes, bank notes, checks, bonds and certified checks. Thus the term "negotiable instrument" had different statutory meanings in the different states. Any new statute with a new definition of the tern would give it a double meaning in any state where it had already been defined by a whole conflicting set of parallel statutes. The alternative would be repeal of the old statutes with the consequent dislocation of any instrument, such as a bond, which might not be included in the new statute. Partial repeal, that is, repeal of the old statutes as to instruments which were covered in the new, would not solve the difficulty because the ones left out were often made as negotiable as ones certain to be included in the new statute. The question of how far the old instruments in the old statutes were governed by reference by the new statutes would then be raised. If the new statutes repealed the old ones only in so far as they were inconsistent, a mare's nest of interpretation as to what was inconsistent would result; the infiuence of the remaining statutes in the individual states on the new N.I. L. would be such as to destroy any possibility of uniformity.

Those who have argued for a narrow N.I.L., covering only a few instrunuents, have assumed a blissful state of the common law, like that of England, where there were no conflicting enactments outside the new statute. This assumption is unjustified as far as the United States is concerned. The draftsman, therefore, wisely did the only thing he could do: he codifled the whole law of negotiable instruments to permit the repeal of all existing statutes. For practical illustrations of the working of this type of problent see Prudential Investment Company v. Mutual Reserve Life Insurance Company, $137 \mathrm{Kan}$ 659, 21 P.(2d) 373 (1933), where an old New York statute inadvertently adopted in Kansas raised such a problen. See also Beutel, Materials and Cases on Negotiable Paper (1936) c. IX, and authorities there cited; and for a similar mess on documents of title under substitute sections of the uniform acts, see BEUTEL, BANK OFFICERS' HANDBOOK OF Commercial Banking Laws (1939) 74-76. 


\section{The Statutes in Detail}

Upon examining the statutes in detail one is immediately struck by the completeness of statutory law on most of the parts of the subject matter of negotiable instruments, and by the variation in the results obtainable in the different states under any one sub-title of the law.

Formal Requisites. Consider for example the subject of formal requisites, which delights the heart of every teacher of negotiable instruments-the part of the field in which he usually speaks with such confidence on the state of "the law"; here, the statutes were myriad.

The negotiability of promissory notes was aided by statute in forty states, ${ }^{; 115}$ but the particular requirements to be met in order to achieve that status were as the poles apart. One would suppose that a promissory note, at least, had to be in writing; but Oregon and Nevada specifically stipulated that they might be telegraphed.110 At least five states $^{117}$ had no requirements for negotiability in the statutes other than that the instrument should be a note, thus raising the old English question whether a note to be negotiable need not be payable to order or bearer $;^{118}$ but here the similarity to the English common law ceased. Twenty-two states ${ }^{110}$ stipulated that instruments payable to order or bearer were negotiable, and at least $\operatorname{six}^{120}$ made it mandatory as does the N. I. L. Iowa ${ }^{121}$ combined both tests and allowed negotiability of notes payable to a person, to his order, or to bearer. Two others covered order instruments only, ${ }^{122}$ while four states provided that notes payable

${ }^{115}$ Alabama, § 869; Arkansas, § 489; California, § 3095 ; Colorado, \$244; Connecticut, §1858; Delaware, p. 527; Georgia, \$\$ 3677, 3682; Illinois, p. 2789, §4; Indiana, \$ 7520; Iowa, \$3043; Kansas, \$1, p. 591 ; Kentucky, \$ 478,483 ; Maryland, Art. 15, p. 106; Massachusetts, $\$ 14$, p. 427; Michigan, $\$ 1577$; Minnesota, \$2220; Mississippi, \& 3502; Missouri, \& 733; Montana, \$156, p. 636; Nebraska, $\$ 3380$ (but issue to circulate as money was a crime, section 6808); Nevada, \$2747; New Jersey, § 2604; New Mexico, § 2545; New York, § 1, p. 278; North Carolina, $\$ \S 41,2286$; North Dakota, $\$ 4861$; Ohio, $\$ 3171$; Oklahoma, para. 3291 ; Oregon, \$3188; Pennsylvania, \$1, pp. 188, 1369, \$2, p. 1370; Rhode Island, \$7, p. 494; South Carolina, \& 1393; South Dakota, \& 5667; Tennessee, \& 2713; Utah, § 1561; Virginia, § 2849; Washington, § 2192; West Virginia, c. 99, §7; Wisconsin, § 1675; Wyoming, § 2337.

${ }_{116}$ Oregon, $\S 4171$; Nevada, $\$ 1065$. It should be noted that these sections also applied to checks and due bills, but quaere whether the latter were negotiable.

${ }^{117}$ Colorado, Illinois, Mississippi, Montana, and North Carolina. See their statutes cited supra note 115 . The last state specifically specified that the note need not be to order or bearer.

${ }^{113}$ See 2 Street, Foundations of Legal LiabiL.1Ty (1906) 386 ct seq.

113 California, Connecticut, Georgia, Indiana, Kansas, Maryland, Michigan, Missouri, Nevada, New Jersey, New Mexico, New York, North Dakota, Oklahoma, Oregon, Rhode Island, South Carolina, South Dakota, Utah, Washington, Wisconsin and Wyoming, in the sections cited supra note 115.

${ }^{100}$ California, North Dakota, Oklahoma, South Dakota, Utah, Wyoming, in the sections cited supra note 115

121 Iowa, \$ 3043.

Pennsylvania and Tennessee, in sections cited supra note 115. 
to order or to bearer or to assigns ${ }^{123}$ were negotiable. Some states added the requirement that notes to be negotiable should be issued by, ${ }^{124}$ or payable at, ${ }^{125}$ or assigned by, banks. ${ }^{126}$ There were also a number of minor special requirements, such as the necessity for the words "value received,"127 "without defalcation or set off"128 to appear on the instrument. On sealed instruments in North Carolina, a holder got only the rights of the payee. ${ }^{129}$ In five states though the holder could sue in his own name, notes were practically non-negotiable by statutory enactment. ${ }^{130}$

The fact that bonds had been made negotiable by colonial statutes and early enactments in the original states caused them to retain this quality in the early decisions. ${ }^{131}$ Nevertheless, statutes in aid of their negotiability were specifically enacted in twenty-one states. $^{132}$ In $\operatorname{six}^{133}$ of these states they were subject to all the provisions of the negotiable instruments codes just as they now are under the N.I. L., while in five ${ }^{134}$ others they were negotiable in the same manner as both bills of exchange and promissory notes. In three states ${ }^{135}$ they were negotiable on the same basis as promissory notes, while in still three others ${ }^{136}$ they had to meet special formal requisites which included the

${ }^{123}$ Delaware, p. 527; Kansas, §1, p. 591; Nebraska, §3380; Ohio, § 3171.

12. Maryland, Art. 15, p. 106.

${ }^{200}$ Alabama, $\$ 869$; Indiana, $\$ 7520$, loan or deposit companies also added, \$ 5012; Kentucky, § 483; Virgina, § 2849; West Virginia, c. 99, § 7.

${ }^{123}$ Kentucky, § 483; North Carolina, § 2286.

$17 \pi$ Missouri, \&733; cf. Tennessee, \$2714.

Im Pennsylvania, §1, p. 1369; and perhaps New Jersey, Laws of New Jersey 1799 (Paterson), pp. 341-342.

${ }_{1=}$ North Carolina, $\$ 41$; contra in Minnesota, $\$ 2220$, where such instruments were fully negotiable.

${ }_{100}$ Arkansas, § 489; Delaware, p. 527; Florida, § 1073; Mississippi, §3503; New Mexico, \$2540.

${ }^{131}$ E.g., Overstreet v. Randolph, Wythe 47 (Va. 1789); Commonwealth ext rel Hamilton v. City of Pittsburgh, $34 \mathrm{~Pa} .496$ (1859), and cases cited infra note 234.

${ }^{132}$ Alabama, $\$ 869$, but bonds to circulate in place of money were penalized 50 per cent, and "change bills" and "shinplasters" were prohibited, \$\$ 866-868; Arkansas, 489 (probably affected only their assignability; California, \$3095; Colorado, \$\$ 243, 244; Delaware, p. 527 (assignable under seal); Georgia, § 3682; Illinois, $\$ \S 3,4$, pp. 2782, 2789; Indiana, $\$ 7515$ (But. cf. $\$ 7516$ ); Kansas, $\S 1$, p. 591 ; Kentucky, $\$ 474$ (subject to defences against original obligor or assignor before notice of assignment); Massachusetts, $\$ 4$, p. 426 (where issued by corporation or joint stock company); Minnesota, $\$ 2220$ (where issued by corporation or joint stock company); Nebraska, $\$ 3380$ (but issue to circulate in place of money was a crime, $\$ 6808$ ); North Carolina, $\$ 50$ (but if under seal indorsee got rights of payee, \$41; North Dakota, \$ 4861; Ohio, \$3171; Oklahoma, \$ 3291; South Dakota, § 5667; Tennessee, \$\$ 2713, 2714; Utah, § 1561; Wyoming, \$2337.

California, \$ 3095; North Dakota, \$ 4861 ; Oklahoma, \$3291; South Dakota, \$ $5667 ;$ Utah, \& $1561 ;$ Wyoming, § 2337 .

${ }^{134}$ Alabama, § 869 ; Illinois, \$ 3, p. 2782, § 4, p. 2789 ; Indiana, \$ 7515; Colorado, $\$ \S 243,244$; Georgia, \$3682.

${ }_{13}$ Massachusetts, § 4, p. 426; Minnesota, §2220; Tennessee, § 2714.

${ }^{130}$ Kansas, $\$ 1$, p. 591 ; Nebraska, $\$ 3380$ (by this section bonds were also negotiable if payable to "assigns") ; Ohio, $\$ 3171$. 
requirement of being payable to order or to bearer. Four states' statutes made bonds wholly or partly non-negotiable. ${ }^{137}$

Even the lowly due bill was covered by the laws of five states. ${ }^{138}$ Two of these clearly made it negotiable; ${ }^{\mathbf{1 3 9}}$ and two provided for making it by telegraph, but left its negotiability in doubt. ${ }^{140}$

Since the bill of exchange was the one instrument to which the English common law from the beginning accorded the quality of negotiability, one would not expect to find many statutes prescribing its formal requisites. But, despite this fact, fourteen states, ${ }^{141}$ other than the seven code states, had statutes on bills of exchange. In other words, at least twenty-one states in all prescribed the form or negotiability of this type of paper. ${ }^{142}$ In all except two of these, ${ }^{143}$ they of course had to be in writing. Eight states required them to be to order or bearer, ${ }^{144}$ two to order, bearer, or assigns, ${ }^{145}$ one to order, ${ }^{146}$ and eight were silent on this point. ${ }^{147}$ Wisconsin provided that instruments drawn upon or accepted by officers, municipalities, and the like, should not be negotiable unless expressly authorized by law. ${ }^{148}$

On the question of the formal requisites of acceptance, the American statutory law differed widely from the English common law. As was the case in England before the B. E. A., ${ }^{149}$ it was required by statute in twenty-four states that the acceptance of the bill be in writ-

${ }^{137}$ Delaware, p. 527; Florida, \$1073; New Mexico, §2540; North Carolina, $\S 41$ (where holder got rights of the payee).

${ }^{233}$ Colorado, § 243; Illinois, § 3, p. 2782; Nevada, § 1065 ; New Mexico, § 2540; Oregon, \$ 4171 .

${ }^{133}$ Colorado and Illinois. See note 138 supra. It should be noted that numerous other statutes mention "bills" together with promissory notes or bonds; but their framers probably had in mind either the old meaning of the term, which is synonymous with "promissory note," or the newer meaning, which is "bill of exchange." However, they are open to the other interpretation, and here the numerous old cases holding due bills to be promissory notes might have great significance.

${ }_{100}$ Nevada and Oregon. See note 138 supra.

11 Arkansas, § 487; Georgia, \$3676; Indiana, \$7515; Kansas, §1, p. 591; Mississippi, §3504; Montana, §156, p. 636; Nebraska, §3380; Nevada, \$1065; Ohio, §3171; Oregon, § 4171; Pennsylvania, §1, p. 188, §2, p. 1370; Virginia, $\$ 2849$; West Virginia, c. 99, § 7; Wisconsin, $\$ 1675$.

${ }_{113}$ The statutes discussed here are only those using the specific term, "bills of exchange." Those using the ambiguous word "bills," which has often been interpreted to mean bills of exchange, are not considered.

${ }_{143}$ Nevada, $\$ 1065$; Oregon, $\S 4171$. (Bills of exchange could be made by telegraph.)

${ }_{14}$ California, $\$ \$ 3087,3171$, and cf. North Dakota, § 4914, Oklahoma, para. 3344, South Dakota, § 5720, Utah, § 1612, and Wyoming, § 2393; Georgia, § 3676; Kansas, §1, p. 591.

${ }_{14}$ Nebraska, § 3380, Ohio, \$ 3171 .

14 Pennsylvania, \& 1 , p. 188 , \&2, p. 1370.

${ }^{47}$ Arkansas, § 487; Idaho, § 2911; Indiana, \$7515; Mississippi, § 3504; Montana, § 156, p. 636; Virginia, §2849; West Virginia, c. 99, § 7; Wisconsin, § 1675.

${ }_{140}$ Wisconsin, $\$ 1675$.

${ }^{30}$ See English Bills of Exchange Act (1878), 41 \& 42 VIcr., c. 13, specifically reenacting the Mercantile Law Amendment Acts of England and Scotland of 1856. 
ing. ${ }^{150}$ But unlike the English statutes which required the acceptance to be written on the bill, ${ }^{151}$ the American statutes all omit this requirement. Sections 133 to 135 of the N. I. L., which allow extrinsic acceptance, have often been criticized for not following the English statute. It is well known that they were taken almost verbatim from a New York statute ${ }^{152}$ which obviously approved the American custom of accepting bills and checks by letter or wire and also the universal custom of accepting bills in advance by letter of credit. In addition to New York, statutes of this nature were in force in fourteen ${ }^{153}$ states; sections corresponding to sections 133 and 135 of the N. I. L. were found in all fourteen, and the provisions of section 134 of the N. I. L. were present in twelve. ${ }^{154}$

Sections similar to 136 and 137 of the N. I. L. regulating the time allowed for acceptance, which were copied from statutes in Massachusetts and New York respectively, ${ }^{155}$ appear in fifteen ${ }^{156}$ states; but none of the old statutes contain the neat correlation between the two sections which appears in the N. I. L. ${ }^{157}$

Statutes governing the formal requisites and negotiability of checks were not so numerous, but checks were specifically named and made negotiable by the statutes of ten states. ${ }^{158}$ There were specifications

${ }^{100}$ Alabama, §880; Arkansas, §475; California §3193; Connecticut, Conn. Pub. Acts 1893, p. 40; Idaho $\$ 2922$; Kansas, $\S 10$, p. 94 ; Maine, $\S 10$, p. 335 ; Michigan, § 1583; Minnesota, § 2233; Mississippi, § 3515; Missouri, §719; Nevada, \$2752; New Mexico, \$2546; New York, \&6, p. 279; North Dakota, \$ 4927; Oklahoma, para. 3357; Oregon, \& 3194; Pennsylvania, \$ 2, p. 188; South Carolina, \$1395; South Dakota, § 5733; Utah, § 1624; Washington, §2199; Wisconsin, \$1681; Wyoming, \$2405.

10 See note 149 sipra, and B. E. A. $\$ 17$ (2) (a). 45 \& 46 VIcT., c. 61 (1882). ${ }_{102}$ N. Y. REv. STAT. (1830) pt. II, tit. II, c. $4, \$ \$ 78$ and 79; see Commissioner's Notes to $N$. I. L. $\$ \$ 133-135$, BeuTEL, CASES AND Materials oN NEgoTTABLE PAPER (Supp. 1936) 39.

${ }_{103}$ Alabama, § 882; Arkansas, § 478; California, § 3194 ; Idaho, § 2923; Kansas, \$ 13, p. 594; Mississippi, \$ 3515; Missouri, \$ 722; Nevada, \$ 2755; North Dakota, $\$ 4928$; Oklahoma, para. 3358; South Dakota, \$ 5734; Utah, \$ 1625; Washington, $\$ 2202$; Wyoming, $\$ 2406$.

154 Arkansas, \$ 476; California, \$ 3196; Idaho, \$2925; Kansas, \$11, p. 594; Missouri, $\$ 720$; Nevada, $\$ 2753$; North Dakota, $\$ 4930$; Oklahoma, para. 3360 ; South Dakota, \$ 5736; Utah, \$1627; Washington, \$2200; Wyoming, \$2408.

${ }_{25}$ See Commissioners Notes to $N$. I. L. \$\$ 136-137, cited supra note 152.

${ }^{100}$ Sections like N. I. L. \$136: California, \& 3186; Idaho, \$2918; Massachusetts, $\$ 17$, p. 428 [cf. Amended Mass. Supp. to Stat. (1889-1895) c. 415, p. 1375]; North Dakota, § 4923; Oklahoma, para. 3353; Rhode Island, \$ 5, p. 494; South Dakota, $\$ 5729$; Utah, \$1620; Wyoming, \$2400. Sections like N. I. L. \$137: Alabama, § 884; Arkansas, \$ 480; California, \$ 3195; Kansas, \$15, p. 594; Missouri, \$724; Nevada, \$2757; New York, \$11, p. 279; North Dakota, \$ 4927; Oklahoma, para. 3359; South Dakota, § 5735; Utah, \$1626; Washington, § 2204; Wyoming, § 2407.

IT See Brannan's Negottable Instruments Law (Beutel 6th ed. 1938) 1093. 100 California, $\$ \$ 3095$, 3254; Idaho, $\$ 2956$; North Dakota, $\$ \$ 4861,4964$; Oklahoma, para. 3291, 3394; Pennsylvania, § 1, p. 188, \$2, p. 1370; South Dakota, \$ 5667. 5770; Utah, \$\$1561, 1653; Virginia, \$2849; West Virginia, c. 99, §7; Wyoming, \$\$ 2337-2440 (cf. id. at \$2442). 
in two others that they might be drawn by telegraph, ${ }^{160}$ and they were undoubtedly considered to be covered by statutes making "bills" payable at banks negotiable. ${ }^{160}$ Even without specific provisions directly touching this point, many states regarded checks as a kind of bill of exchange, subject to the statutes regulating those instruments; but this is a question of interpretation which will not be considered here.

In addition to the standard types of negotiable instruments already mentioned, there were many others which enjoyed some or all of the attributes of negotiability. Chief among these were the instruments payable in goods, which had been negotiable from colonial times. Statutes giving these instruments unusual circulation still survived in seven states. ${ }^{161}$ Negotiable instruments thus payable in goods included notes, ${ }^{102}$ bonds, ${ }^{163}$ bills, $^{164}$ specialties $^{165}$ and even bills of exchange. ${ }^{166}$ Such instruments in two states ${ }^{167}$ might also be payable in labor, and in one other, bills, drafts and checks payable in depreciated bank notes or current funds were negotiable.168

Liability of Parties. On the matter of liability of parties and the defenses which they could offer, the statutes presented an interesting and varied picture.

In seven states presentment was not necessary to charge the principal debtor instead of the person primarily liable. ${ }^{169}$ Presentment was necessary before the maker of a demand note could be sued in Maine. ${ }^{170}$ In Colorado, where the instrument was payable in goods, tender to the payee discharged the maker and transferred title to the goods promised. ${ }^{171}$ And in Iowa a defrauded maker was required only to pay a bona fide holder the amount the holder had paid for the instrument. ${ }^{172}$

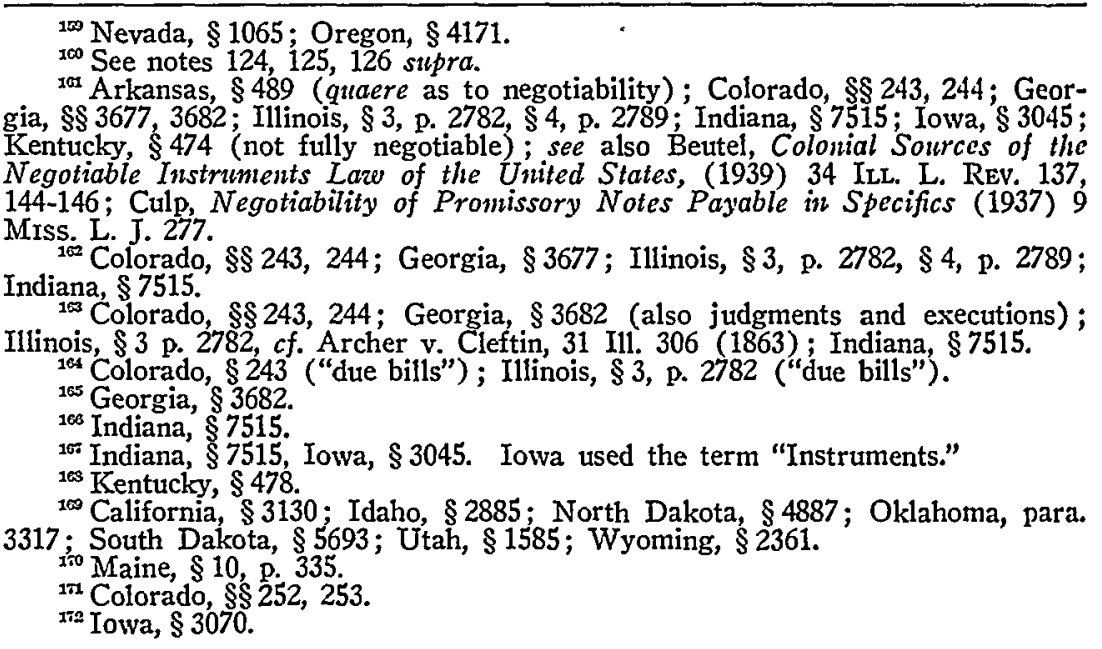


In the seven code states an acceptor admitted the signature of the drawer, but not that of the indorser ; ${ }^{173}$ and in one of these, ${ }^{174}$ he was not liable to pay according to the tenor of his acceptance if the instrument had been raised. In these same seven code states, one who was not a drawee could accept a bill, in which case it became a promissory note discharging all prior parties. ${ }^{175}$

The liability of the drawer was subject to many variations. In one state the drawer of an unaccepted bill of exchange was primarily liable thereon. ${ }^{176}$ In three others, he was subject to suit without notice of dishonor, ${ }^{177}$ but the rule was contra in another three where due diligence was a condition precedent to liability. ${ }^{178}$ In the code states his liability was that of a first indorser. ${ }^{179}$

On the question of indorsers' liability, the statute makers really had a field day. Twenty-five states had statutes creating various types of obligations. The liabilities of indorsers of notes and bonds often differed from those of indorsers of bills of exchange, even within the same state. ${ }^{180}$ This liability might be primary for indorsers of unaccepted bills of exchange, ${ }^{181}$ secondary without the necessity of protests or notice, ${ }^{182}$ conditioned on due diligence, ${ }^{183}$ or absolute upon the bringing of suit against prior parties. ${ }^{184}$ So also the indorser might be liable as a surety, ${ }^{185}$ a guarantor, ${ }^{186}$ an assignor ${ }^{187}$ or as a guarantor conditioned upon diligence. ${ }^{188}$ The anomalous indorser found himself liable in the same manner as any other indorser in eight states; $;^{189}$ in one, such liability attached even though the instrument was non-negotiable. ${ }^{190}$

${ }^{173}$ California, § 3197 ; Idaho, §2928; North Dakota, § 4933; Oklahoma, § 3363; South Dakota, § 5739; Utah, \$1630; Wyoming, \$2411.

${ }_{17:}$ California, \$ $\$ 246$; Idaho, \$2960; North Dakota, § 4961; Oklahoma, para. 3391; South Dakota, \$5767; Utah, \$1660; Wyoming, \$2437.

${ }_{1 \rightarrow 0}$ Montana, \& 159, p. 636.

177 Arizona, \$120; Ohio, § 3175 ; Texas, art. 306.

${ }^{178}$ Colorado, \$ 241 ; North Carolina, \$ 42; South Carolina, § 1395.

17 California, \$ 3177; Idaho, \$2916; North Dakota, \$ 4920; Oklahoma, para. 3350; South Dakota, \$ 5726; Utah, § 1618; Wyoming, \$ 2398.

${ }_{103}$ For example, Montana, compare $\$ 159$ with $\$ 160$, p. 636 ; Colorado, compare $\$ \$ 241,242,247$; Illinois, compare $\$ 12$, p. 2801 (bearer paper) with $\$ 7$, p. 2796 (instruments payable in money).

${ }^{151}$ Montana, $\$ 159$, p. 636; Ohio, \$ 3175 .

15: North Carolina, $\$ 50$.

153 Colorado, \$\$ 241, 242; Georgia, \$ 3688; Illinois, \$7, p. 2796; Montana, $\$ 180$, p. 636; North Carolina, \$ 42 ; South Carolina, \$1395.

ist Arizona, \$120; Colorado, \$247; Texas, art. 306 (bills of exchange).

${ }^{25 s}$ North Carolina, $\S 50$.

${ }^{100}$ Illinois, \$ 12, p. 2801.

${ }^{25}$ Kentucky, \$ 481 .

ss Indiana, \$3049.

${ }^{250}$ California, $\$ \S 3108,3117$; Connecticut, $\$ 1860$; Massachusetts, $\S 15$, p. 427 ; North Dakota, $\$ \$ 4868,4877$; Oklahoma, para. 3298, 3307; South Dakota, $\$ \$ 5674$, 5683; Utah, \$\$ 1568, 1577; Wyoming, \$\$ 2344, 2351.

ivo Connecticut, $\$ 1860$. 
In at least eight states, the indorser's liability in warranty was firmly established by the statutes; ${ }^{191}$ but an examination of the particular sections will reveal that the warranties were not identical. In four states it was stipulated that the liability of indorsers on demand notes was the same as that on time notes. ${ }^{122}$

Seventeen states had statutes whose provisions collectively covered most of the material found in sections $25-29$ and 59 of the N. I. L., but with interesting variations. Arizona and Texas had statutes providing that want or failure of consideration was a defense against the payee and transferees with notice and after maturity. ${ }^{103}$ This probably accounts for one of the leading cases holding that a payee could not be a holder in due course. ${ }^{104}$ Three other states allowed a bona fide assignee to cut off these defenses ${ }^{195}$ and one of these ${ }^{100}$ stipulated value in addition to bona fides. Eight states ${ }^{197}$ provided that absence of consideration was no defense against a holder for value, thus reaching approximately the same result as section 29 of the N. I. L. In nine states $^{188}$ there was a presumption of consideration for all parties; in one it was clearly rebutable, ${ }^{199}$ and in one it appeared absolute..$^{200}$ Pennsylvania had an act providing that where an instrument was forged a holder could get his money back, ${ }^{201}$ and Arkansas and Delaware provided that, after assignment, no assignor could release any part of the consideration. ${ }^{202}$

Rights of Holders. In thirty-five states, ${ }^{203}$ statutes gave the holder

${ }^{191}$ California, \$3116; Georgia, §3685; Idaho, § 2878; North Dakota, §4876; Oklahoma, para. 3306; South Dakota, \$ 5682; Utah, \$1576; Wyoming, \$2350.

${ }^{102}$ Massachusetts, $\$ 13$, p. 427; Minnesota, $\$ 2232$; New Hampshire, $\$ 6$, p. 570; Vermont, $\$ 2321$; cf. the Illinois sections cited supra note 180 for a probable reason for such statutes.

${ }^{120}$ Arizona, \$ 128; Texas, art. 314. (1927).

J. I. Case Threshing Machine Co. v. Howth, 116 Tex. 434, 293 S. W. 800

${ }^{105}$ Colorado, $\$ 250$; Illinois, $\$ 13$, p. 2802; Iowa, $\$ 3070$.

${ }^{100}$ Iowa, $\$ 3070$.

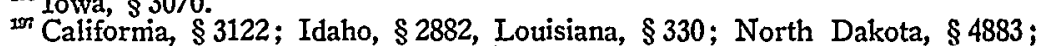

Oklahoma, para. 3313; South Dakota, \$ 5689; Utah, \& 1581; Wyoming, \& 2357

${ }^{103}$ Arkansas, \$ 498; California, \$3104; Georgia, \$3696; Idaho, \$2870; North

Dakota, \$ 4867; Oklahoma, para. 3297; South Dakota, \$5673; Utah, \$1567; Wyoming, $\$ 2343$.

${ }^{100}$ Georgia, \$ 3696

200 Arkansas, \$ 498 .

Section 10, p. 190, \$ 8, p. 1371 .

32 Arkansas, $\$ 501$; Delaware, p. 527

Alabama, \$28; Arizona, \$121; California, \$3120; Colorado, \$245; Delaware, p. 527; Florida, § 1073; Georgia, § 3698 ; Idaho, § 2881; Illinois, § 5, p. 2795; Indiana, \$ 7516; Kansas, \$ 8, p. 594; Michigan, \$ 1579; Minnesota, \$ 4994; Mississippi, \$\$ 3503, 3504; Missouri, \$ 734; Montana, § 156, p. 636; Nebraska, \$ 3381; Nevada, $\$ 2750$; New Jersey, § 1, p. 2604; New Mexico, \$2540; New York, §4, p. 278; North Carolina, \$41; North Dakota, \$ 4880; Ohio, \$ 3172; Oklahoma, para. 3310; Oregon, $\$ 3190$; Pennsylvania, $\$ 1$, p. 1369; South Dakota, $\$ 5686$; Tennessee, $\$ 2715$; Texas, art. 307; Utah, $\$ 1580$; Vermont, $\$ 2306$; Washington, \$2195; Wisconsin, § 1678; Wyoming, \$§ 2354, 2442. 
of negotiable instruments, or of a particular type of negotiable instrument, the power to sue thereon in his own name; but this might have been subject to the real party in interest statutes in at least two states. ${ }^{204}$

Although the term "holder in due course" had not yet appeared in the statutes, the seven code states used the expression "indorsee in due course." ${ }^{205}$ Thus by implication or direct provision, ${ }^{206}$ they excluded the payee from this charmed circle. Such a bona fide transferee for value specifically cut off defenses, set-offs and defects of title in whole or in part under the statutes of fifteen states. ${ }^{207}$ In nine states, he could recover on instruments void for various kinds of illegality ${ }^{208}$ but in eight others, ${ }^{209}$ the holder in due course was specifically subject to one or more defenses which he now cuts off under the N. I. L.

The holder of overdue paper was made the subject of special regulation in twenty-one states, but his rights were as varied as Joseph's coat. In five states the purchaser, after maturity, took subject to the defenses existing against the payee. ${ }^{210}$ In Illinois he was subject to the defense against the payee and all intermediate holders. ${ }^{211}$ Six other states provided that instruments were subject to set-off and defenses existing against the transferor, but that if they were negotiated before maturity, this rule did not apply. ${ }^{212}$ Five prescribed that the purchaser after maturity was subject to the set-offs or discounts that were good against his assignor. ${ }^{213}$ In Minnesota usury made an instrument void as against a purchaser after maturity no matter what its previous history had been, ${ }^{214}$ while in three states illegality seems to have been cut

204 Arkansas, \$5623; Arizona Seventeenth Territorial Session Laws (1893) p. 17, tit. 20, c. 680, \$32. Cf. ARIz. REV. STAT. (1887) \$121.

California, \$3123; Idaho, \$2883; North Dakota, \$4884; Oklahoma, para. 3314; South Dakota, § 5690; Utah, § 1582; Wyoming, § 2358.

300 North Dakota, \$ 4884 .

2m Alabama, \$3733; Arizona, §681; Arkansas, §492; California, §3124;

Georgia, \$ 3694; Iowa, \$ 3461 ; Montana, \$ 5, p. 61 ; North Carolina, \$177; North

Dakota, § 4885; Oklahoma, para. 3315; Oregon, §28; South Dakota, §5691;

Texas, art. 307; Utah, \$1583; Wyoming, \$2359.

${ }_{200}$ California, \$3124; Iowa, \$2423; Massachusetts, § 5, p. 522; Maine, §56, p. $312, \S 10$, p. 913 ; Minnesota, $\$ 2214,6594$; North Dakota, $\$ 4885$; Oklahoma, para. 3315; South Dakota, §5691; Utah, \$1583.

Dorth Carolina $\$ 41$ (seal same rights as payee); Pennsylvania, $\$ 1$, p. 1369 (negotiable with certain words); Illinois, \$14, p. 2808, and Minnesota, \$2239 (subject to something like fraud in the factum) ; Indiana, $\$ \$ 7517,7518$, Mississippi, §3503, New Mexico, \$2540, and probably Delaware, p. 527 (many otherwise negotiable instruments, wholly or partly non-negotiable).

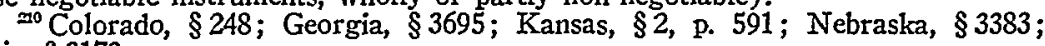
Ohio, $\$ 3173$.

ais Illinois, §15, p. 2811

${ }^{20}$ Arizona, $\$ 681$; Colorado, $\$ 251$; Iowa, $\S 3461$; Montana, $\$ 5$, p. 61; North Carolina, \$177; Oregon, \$28.

${ }_{213}$ Arizona, § 121; Illinois, § 16, p. 2811; MICH. GEN. STAT. (1883-1890) §7635;

Minnesota, § 4994; Texas, art. 307.

$\approx$ Minnesota, $\$ 2214$. 
off by any good-faith purchaser without notice. ${ }^{215}$ In the seven code states, an indorsee of a check, after its apparent maturity but without notice of dishonor, got the same rights as a purchaser before maturity. ${ }^{216}$ In this connection it should be noted that it was not uncommon for different rules to exist in the same state for different types of paper.

Payment to one not a holder was no defense in one state.217 In two others, ${ }^{218}$ payment after notice of assignment was ineffective, but a purchaser with notice of payment apparently took subject to it in five states. $^{219}$

In three of the code states, discharged instruments were revived in favor of an indorsee in due course. ${ }^{220}$

Maturity and Diligence. Every state in the union, with the possible exception of Kentucky, had one or more statutes affecting the manner of calculating the maturity and time of payment of negotiable instruments. These statutes varied both as to details and general principles and also as to the type of paper involved. Different kinds of instruments were often subject to different rules in a single state, and even practices in counties or cities within some states were governed by varying statutory provisions. ${ }^{21}$ Where the date of maturity fell on Sunday or a holiday, twenty-three states ${ }^{222}$ postponed it to the day following, while fifteen states ${ }^{223}$ placed it on the preceeding day. In six others it might fall either on the preceeding or following day depending upon

${ }^{215}$ Massachusetts, $\S 5$, p. 522; Maine, $\$ \$ 10,56$, pp. 913, 312; Minnesota, $\S 6594$ (gambling).

${ }_{2 \mathfrak{s}}$ California, \$3255; Idaho, §2957; North Dakota, \$4965; Oklahoma, para. 3395; South Dakota, § 5771; Utah, § 1664; Wyoming, \$2441.

${ }_{217}$ Arizona, § 501 .

as Colorado, $\$ 246$; Illinois, $\$ 6$, p. 2795

${ }^{20}$ Colorado, \$249; Illinois, \$17, p. 2812; Kansas, §3, p. 592; Nebraska, \$3384; Ohio, \$ 3174 .

$\approx$ North Dakota, \$4913; Oklahoma, para. 3343; South Dakota, \$5719.

For example, see Maryland, $\$ 9$, 10, p. 116, Md. Laws 1892, c. 462 , p. 656 , id. 1894 , c. 167 , p. 221 , id. 1894 , c. 510 , p. 747 ; Pennsylvania, $\$ 1$, p. 1369. Laws of Missouri 1895, p. 47, cf. Mo. Rev. StAт. (1889) \$737.

Alabama, \$ 872; Arizona, \$ 2070 ; California, \$ 3132 ; Conn. Pub. Acts 1893, p. 463, repealing previous rule (see Conn. Gen. Stat. (1888) § 1862); Idaho, \$2887; Illinois, \$21, p. 2813; Iowa, \$3053; Massachusetts, c. 333, p. 1051; Mich. Pub. Acts 1893, no. 185, p. 299; Nebraska, \$ 3387; New Mexico, \$ 2544; New York, \$\$ 25-27, pp. 281-2; North Dakota, \$4889; Ohio, \$ 3177; Oklahoma, para. 3319; Pa. Sess. Laws 1895, \$2, p. 2661; Rhode Island, \$9, p. 494; South Carolina, \$1404; South Dakota, \$ 5695 ; Vermont, \$\$ 2314, 2317; Virginia, \$2844, p. 412; Wisconsin, § 1684 ; Wyoming, \$2363.

$\approx$ Arkansas, \$ 481, Ark. Laws 1895, p. 192-193; Colorado, \$255; Delaware, pp. 527-8; Florida, \$\$ 2315, 2316; Indiana, \$ 7531; Minnesota, \$2230; Mississippi, \$3514; Montana, $\$ 158$, p. 636; Nevada, \$2766; New Hampshire, \$2, p. 569; New Jersey, \$14, p. 2606; TENN. CoDE (Supp. 1885-1893) §2723; Vermont, \$2318; West Virginia, c. 99, § 3; Wyoming, \$§ 2390-2391. 
the type of paper or the locality involved. ${ }^{224}$ Seven states gave the Saturday half holiday treatment similar to that accorded Sunday. ${ }^{225}$

Thirteen states had statutes providing for maturity of demand paper, which ranged from ten days after issue to the date of demand. ${ }^{226}$

The matter of maturity and diligence was further complicated by the existence of days of grace, now happily abolished, which allowed a further time after maturity for the presentment, payment, or protest of instruments. At least forty-one states ${ }^{227}$ had statutes touching on this subject. They ranged from a small minority abolishing the custom entirely, ${ }^{228}$ or abolishing it for one or more classes of commercial paper, to those allowing as much as four days additional time. ${ }^{229}$ It was not at all unusual to find statutes in the same state allowing different types of grace on various classes of paper, or at the will of the parties. ${ }^{230}$ In fact the matter was so complicated that it is difficult to understand how business men in many states could safely present paper for payment without first obtaining legal advice.

Georgia, compare $\S 3692$ with $\$ 3693$; Maryland, compare $\$ \S 9,10$, p. 116 , Md. Laws 1892 , c. 462 , p. 656 , Md. Laws 1894 , c. 167 , p. 221 , id. c. 510 , p. 747 ; Missouri, § 737, Laws of Missouri 1895, p. 47; Utah, \$1587; cf. also Vermont and Wyoming at sections cited supra notes 222 and 223

${ }_{225}$ Conn. Pub. Acts 1893, p. 463; Georgia, \$ 3693; Md. Laws 1892, c. 462 , p. 656. Md. Laws 1894 , c. 167 (cf. id. c. 510 , p. 747 ) ; MASs. PUB. Stat. (Supp. 1889 $1895)$ c. 201 , p. 1299 , id. at c. 415 , p. 1375 ; Mich. Pub. Acts 1893, no. 1851, p. 299; New York, $\$ \S 25,27$, pp. 281, 282; Rhode Island, $\$ 9$, p. 494.

$\Rightarrow \rightarrow$ In the code states the times ranged from ten days on non-interest bearing bills of exchange to one year on interest bearing notes and drafts; California, $\$ \$ 3134-3136$; Idaho, \$\$ 2889-2891; North Dakota, \$\$ 4891-4893; Oklahoma, para. 3321-3323; South Dakota, \$\$ 5697-5699; Utah, \$\$ 1589-1591; Wyoming, \$\$ 2365, 2366; see also Connecticut, $\$ 1859$; Massachusetts, \$12, p. 427; Minnesota, \$2231; Missouri, \$736; New Hampshire, § 5, p. 570; Vermont, § 2320

Alabama, \$\$ 869-871; Arizona, \$132; Arkansas, \$ 488; California, § 3181 ; Colorado, \$254; Connecticut, \$ 1861, Conn. Pub. Acts 1895, p. 463; Delaware, p. 525; Georgia, $\$ 3679,3680$; Idaho, \$2910; Illinois, \$19, p. 2813; Indiana, \$7528; Iowa, $\$ \$ 3050,3051$; Kansas, $\$ \$ 4,5$, p. 592; Louisiana, $\$ \$ 331,332,324,1114$; Maine, \$ 9, p. 334; Me. Acts and Resolves 1893, c. 298, p. 354; Md. Laws 1896, c. 106 , p. 140 ; Massachusetts, $\$ \$ 9,10$, p. 427; Michigan, $\$ \$ 1581,1582,1587$; Minnesota, \$\$ 2237, 2238; Mississippi, \$ 3508; Montana, \$157, p. 636; Nebraska, \$ 3382; Nevada, $\$ 2767$; New Hampshire, $\$ 1$, p. 569 ; New Jersey, $\$ \$ 3,4$, p. 2604, $\$ 22$, p. 2607; New York, $\$ 1$, p. 829, $\$ \$ 20,21$, p. 281; North Carolina, $\$ 43$; North Dakota, $\$ 4921$; Oklahoma, para. 3351 ; Oregon, $\$ 3193$, Gen. Laws of Oregon 1893 , \$ 3192, p. 104; Pennsylvania, \$ 4, p. 188, Pa. Sess. Laws 1895, \$\$ 1, 2, p. 2661; Rhode Island, \$ 4; South Carolina, § 1399; South Dakota, \$ 5727 ; Tennessee, $\$ 2722$; Texas, art. 318; Utah, \$1611; Vermont, $\$ \$ 2316,2319$; Washington, \$2197; Wisconsin, \$1680; Wyoming, \$\$ 2387-2389.

ma There were only eight such states: California, Connecticut, Idaho, Illinois, North Dakota, Oregon, Utah, Wisconsin (sections cited silpra note 227).

$\approx$ See Me. Acts and Resolves 1893 , c. 298 , p. 354 .

os The majority of the states were probably in this condition. For specific examples see Colorado, Delaware, Georgia, Louisiana, Maryland, Massachusetts, which distinguished between demand and sight instruments, Michigan, Minnesota, Mississippi, Montana, Nebraska, Nevada, New Hampshire, New Jersey, North Carolina, Oklahoma, Pennsylvania, South Dakota, Vermont, Wyoming, all at sections cited supra note 227 . 
Even in England the law on presentment, protest, and notice of dishonor was largely statutory in its origin and development; ${ }^{231}$ and the states on this side of the ocean also found the statutes their chief source of law on this subject. In addition to statutes on days of grace, all but eleven ${ }^{232}$ of the states had enactments which covered, among their collective provisions, almost every detail now found in the sixtythree sections of the N. I. L. on the subject. To cite the various provisions of these laws in detail would serve only to burden further an already too tedious discussion of antiquated statutes; but one desiring to do so may find here a fruitful field of research which will yield a maze of conflicting and detailed rules that would delight the heart of the most pedantic scholar, and which confounded the business community.

\section{Concluston}

No purpose would be served by citing and discussing at length many other state statutes appearing in one or more states which governed various special aspects of negotiable paper; but it is worthy of remark that these states were so numerous that their citations would constitute a volume of material nearly equal to that of the ones already covered. Each with its own detailed provisions added just a mite to the general confusion that was the law of commercial paper in the United States.

In a situation of this sort, it is doubtful whether any generalizations are possible, but a few may be suggested. The basic common law of negotiable paper of each state was statutory in its origin. Its nature depended upon the date and wording of the enabling statutes which differed radically in their results in various states. The early court decisions thereafter were influenced by remnants of colonial laws and customs which had no counterpart in England, but which developed into a multitude of conflicting statutes adopted to meet local conditions. Without discussing the various conflicting decisions on points not directly covered by statutes in particular states-they are familiar to every student of bills and notes-, it should be noted that due to the courts' habit of following or ignoring statutes without citing them, ${ }^{233}$ much of

The following are a brief list of authorities which played an active part in developing the English Law: 9 \& 10 WM. III, c. 17 (1698); 3 \& 4 ANNE, c. 9 , $\$ 4$ (1704) [broadly construed in Heylyn v. Adamson, 2 Burr. 669, 2 Kenyon 379 (1758)]; $7 \& 8$ GEO. IV, c. 15 (1827); 9 GEo. IV, c. 24 (1828).

Tse The states where such statutes seem to have been lacking are Colorado, Georgia, Illinois, Indiana, Kentucky, Maryland, Missouri, North Carolina, Oregon, Washington and Wisconsin, but one cannot say categorically that these states were entirely without statute law on the subject because all but Kentucky had statutes on days of grace which often had a vital effect in practice.

${ }_{233}$ For a discussion of this tendency see Beutel, The Necessity of a New Technique of Interpreting the N.I. L. (1931) 6 Tulane L. Rev. 1, 5, and articles by Mr. Eaton there cited. 
what has been taken for common law in various states is the direct result of decisions applying these statutes ${ }^{234}$ or following cases in other states which relied upon the statutes. ${ }^{235}$ Finally, the laws on the statute books governing negotiable instruments were in fundamental conflict on almost every question of importance to the commercial community. Under these circumstances, to talk about a common law of bills and notes in the United States is to indulge in a form of transcendental nonsense which often yields ridiculous results. ${ }^{236}$

College of Willtam and Mary.

Frederick K. BeUtel

For example, in Steffen and Russell, The Negotiability of Corporate Bonds (1932) 41 YALE L. J. 799, 803, the authors state that "bonds payable to bearer and under seal were uniformly held negotiable." Yet five of the cases on point which they cite were controlled directly by statutes usually cited therein. See Chaplin v. Vermont and Massachusetts Ry., 74 Mass. 575, 577 (1857) ; Morris Canal Banking Co. v. Fisher, 9 N. J. Eq. 667, 698 (1855); Ohio ex rel. Garrett v. Van Horne, 7 Ohio St. 327, 330 (1857) ; Commonwealth ex rel. Hamilton v. City of Pittsburgh, $34 \mathrm{~Pa} 496$ (1859) (citing no act. But see Bunting's Administrators v. Camden and Atlantic Ry., $81 \mathrm{~Pa} .254,255$ (1876), where the court cites the controlling act of 1715).

$\approx z 5$ For example, see CAMrpbell, CASEs on Birls AND Notes (1928) 159 n, stating that in Alabama notes were negotiable by common law, citing Dunn $v$, Adams, 1 Ala 527, 529 (1840). It is interesting to observe that the case involved a Georgia note which had been made negotiable by the statute of that state, see note 89 supra. For other examples, see Commonwealth ex rel. Hamilton v. City of Pittsburgh, $34 \mathrm{~Pa} .496$ (1859), and Clark v. Janesville, 10 Wis. 119, 128, 167 (1859), relying on Commissioners of Knox County v. Aspinwell, 21 How. 539 (U. S. 1858), both decided under statutes, but cited by Steffen and Russell, loc. cit. stupra note 234, as if they were common law cases.

$\stackrel{0}{0}$ For example, see Deuselman v. Brazier, 193 Mass. 588, 79 N. E. 812 (1907), holding that days of grace still existed in New York though they had been abolished by statute twenty-two years before (see New York $\$ 1$, p. 829) and again with the adoption of the N. I. L. (Laws of New York 1897, c. 612, \$ 85); cf. the more sensible result in Gleason v. Thayer, 87 Conn. 248, 87 Atl. 790 (1913). See also Crume v. Brightwell, 69 Ind. 404, 122 N. E. 230 (1919), holding that the common law of Georgia was the law merchant, and that by the law merchant notes could not be negotiable; both assumptions being fallacious. Notes were negotiable at law merchant; but Georgia had no common law on the subject. Negotiability of notes had been settled there by the statutes for one hundred and twenty years. See note 89 , supra. See also the authorities and comment in Brannan's Negotiable Instruments Law (Beutel, 6th ed. 1938) 1120. 